\title{
Age-Dependent Effect of Oxidative Stress on Cardiac Sarcoplasmic Reticulum Vesicles
}

\author{
E. BABUŠÍKOVÁ ${ }^{1}$, M. JESEŇÁK ${ }^{2}$, D. DOBROTA ${ }^{1}$, N. TRIBULOVÁ ${ }^{3}$, P. KAPLÁN $^{1}$ \\ ${ }^{1}$ Department of Medical Biochemistry, Centre of Excellence for Cardiovascular Research of Slovak \\ Academy of Sciences, Jessenius Faculty of Medicine, Comenius University, Martin, ${ }^{2}$ Department of \\ Pediatrics, Martin Faculty Hospital, Martin, ${ }^{3}$ Institute for Heart Research Slovak Academy of \\ Sciences, Bratislava, Slovak Republic
}

Received January 25, 2008

Accepted March 25, 2008

On-line March 28, 2008

\begin{abstract}
Summary
The oxidative stress hypothesis of aging suggests that accumulation of oxidative damage is a key factor of the alterations in physiological function during aging. We studied age-related sensitivity to oxidative modifications of proteins and lipids of cardiac sarcoplasmic reticulum (SR) isolated from 6-, 15and 26-month-old rats. Oxidative stress was generated in vitro by exposing SR vesicles to $0.1 \mathrm{mmol} / \mathrm{l} \mathrm{FeSO}_{4} /$ EDTA $+1 \mathrm{mmol} / \mathrm{H}_{2} \mathrm{O}_{2}$ at $37^{\circ} \mathrm{C}$ for $60 \mathrm{~min}$. In all groups, oxidative stress was associated with decreased membrane surface hydrophobicity, as detected by 1-anilino-8-naphthalenesulfonate as a probe. Structural changes in SR membranes were accompanied by degradation of tryptophan and significant accumulation of protein dityrosines, protein conjugates with lipid peroxidation products, conjugated dienes and thiobarbituric acid reactive substances. The sensitivity to oxidative damage was most pronounced in SR of 26-month-old rat. Our results indicate that aging and oxidative stress are associated with accumulation of oxidatively damaged proteins and lipids and these changes could contribute to cardiovascular injury.
\end{abstract}

\section{Key words}

Oxidative stress $\bullet$ Reactive oxygen species $\bullet$ Protein damage $\bullet$ Heart

\section{Corresponding author}

Eva Babušíková, Comenius University in Bratislava, Jessenius Faculty of Medicine in Martin, Department of Medical Biochemistry, Mala Hora 4, 03601 Martin, Slovak Republic. E-mail: babusikova@jfmed.uniba.sk

\section{Introduction}

All organisms are permanently exposed to exogenously and endogenously generated reactive oxygen and nitrogen species (ROS/RNS). ROS/RNS serve as signal molecules at low concentration, but evoke harmful, pernicious effects if they are produced in oversize amounts (Dhalla et al. 2000). Although cells has a complex net of antioxidant defense (Bergendi et al. 1999, Pollack and Leeuwenburgh 1999, Sivoňová et al. 2007) this defense is not quite effective, and therefore molecular damage may occur. Unbalance between prooxidants and antioxidants in profit of pro-oxidants causes elevated oxidative stress. Oxidative damage of biomolecules can accumulate (Babušíková et al. 2007, Cakatay et al. 2003, Krajčovičová-Kudláčková et al. 2006) and gene expression can be altered (Kaplán et al. 2007) with advancing age. Some of the oxidative damages may be a base of a functional decay and failure associated with old age and diseases (Ames et al. 1993).

There is evidence that the most important mechanism of oxidative damage to proteins is metalcatalyzed oxidation (Berlett and Stadtman 1997). Hydrogen peroxide is a precursor of hydroxyl radical (the most reactive ROS). Each biological system which produces superoxide also produces hydrogen peroxide by dismutation reaction. Besides superoxide dismutase there are another enzymes producing $\mathrm{H}_{2} \mathrm{O}_{2}$ : amino acid oxidase, glycolate oxidase, urate oxidase, monoamino oxidase, xanthine oxidase, NADPH oxidase (Reiter 1998, Dupuy et al. 1991). Hydrogen peroxide is reduced to 
hydroxyl radical in the presence of transient metal $\left(\mathrm{Fe}^{2+}\right.$, $\mathrm{Cu}^{2+}$ ) by Haber-Weiss or Fenton reaction (Halliwell and Gutteridge 1990). Transient metal are able to split organic hydroperoxides to radicals which initiate chain reaction and initiate lipid peroxidation (Spiteller 2001, Dean et al. 1997). Age-related reduction of ability to degrade oxidative modified proteins can contribute to accumulation of damaged dysfunctional molecules in cell (Shringarpure and Davies 2002). All amino acids are sensitive to hydroxyl damage (Fu et al. 1998, Davies 1987). In the presence of $\mathrm{Fe}^{2+}$ and $\mathrm{H}_{2} \mathrm{O}_{2}$ protein modification occurs at amino acid side chains with metalbinding sites (Stadman and Berlett 1997). Metal catalyzed protein oxidation is probably included in many physiological processes and pathological damages. Aging has a powerful effect on increased susceptibility to cardiovascular diseases even in optimal healthy individuals. Increasing evidence indicates that ROS production in cells increase with the age in mammals (Smith et al. 1991). However cause relationship between protein damage and etiology and development of agerelated diseases is not exactly established. The aim of the present study was to study changes and sensitivity of heart sarcoplasmic reticulum vesicles with advancing age to in vitro induced oxidative stress.

\section{Methods}

\section{Animals}

Male Wistar rats (supplied by IEP SAS Dobra Voda, Slovakia) were divided into three groups according to age, as adult (6-month-old), old (15-month-old) and senescent (26-month-old). The animals were maintained in air-conditioned room $\left(21 \pm 2{ }^{\circ} \mathrm{C}, 12 \mathrm{~h} \mathrm{light/dark} \mathrm{cycle}\right)$. The animals were allowed free access to food and water. Experiments were approved by Ethics Committee of the Jessenius Faculty of Medicine in Martin, as well as with the rules issued by the State Veterinary and Alimentary Administration of the Slovak republic.

\section{Preparation of tissue samples}

Animals were divided into three groups according to age. Each group consisted of 5 animals. The rats were decapitated after $5 \mathrm{~min}$ halothane anaesthesia and hearts were excised. Hearts were washed, minced and homogenized in $10 \mathrm{vol}$ of $30 \mathrm{mmol} / \mathrm{K} \mathrm{KH}_{2} \mathrm{PO}_{4}, 5 \mathrm{mmol} / \mathrm{l}$ EDTA, $0.3 \mathrm{~mol} / 1$ sucrose, $0.5 \mathrm{mmol} / 1$ ditiothreitol, $0.3 \mathrm{mmol} / \mathrm{l}$ phenylmethylsulfonyl fluoride, $1 \mu \mathrm{mol} / 1$ leupeptine, $1 \mu \mathrm{mol} / \mathrm{l}$ pepstatine ( $\mathrm{pH}$ 6.8) with a Ultra-
Turrax T 25 homogenizer (three times for $10 \mathrm{~s}, 20500$ rpm). Homogenates were stored at $-80^{\circ} \mathrm{C}$ or were used for sarcoplasmic reticulum preparation. The sarcoplasmic reticulum (SR) vesicles were prepared as described (Kaplán et al. 2003).

Protein assay was performed by method of Lowry et al. (1951), using bovine serum albumin as a standard.

\section{Oxidation of cardiac sarcoplasmic reticulum vesicles}

Oxidative stress was induced by incubation of sarcoplasmic reticulum vesicles $(3 \mathrm{mg} / \mathrm{ml})$ with $1 \mathrm{mmol} / 1$ $\mathrm{H}_{2} \mathrm{O}_{2}, 0.1 \mathrm{mmol} / 1 \mathrm{FeSO}_{4} / \mathrm{EDTA}$ at $37^{\circ} \mathrm{C}$ for $60 \mathrm{~min}$. Controls in each age group were incubated in the same manner without the treatment with free radical generating system. After the appropriate time intervals, the aliquots of SR vesicles were taken for fluorescence measurements.

\section{Fluorescence measurements}

Fluorescence measurements were performed in solution containing $50 \mu \mathrm{g}$ of proteins per $\mathrm{ml}, 10 \mathrm{mmol} / \mathrm{l}$ HEPES, $100 \mathrm{mmol} / \mathrm{l} \mathrm{KCl}(\mathrm{pH} 7.0)$ at $25{ }^{\circ} \mathrm{C}$ using Shimadzu RF 540 spectrofluorimeter. Fluorescence spectra were measured as previously (Babušíková et al. 2004).

\section{Measurement of lipid peroxidation}

Heart homogenate and sarcoplasmic reticulum vesicles were dispensed in concentration of $20 \mu \mathrm{g} / \mathrm{ml}$ protein in solution with $10 \mathrm{mmol} / \mathrm{l}$ phosphate buffer containing $1 \%$ Lubrol (Braughler et al. 1986). The absorption spectrum was then recorded using Pharmacia LKB Ultraspec III spectrophotometer. The rate of conjugated diene formation was estimated according to the lipid oxidation index, $\mathrm{A}_{233 \mathrm{~nm}} / \mathrm{A}_{215 \mathrm{~nm}}$, which provides a sensitive method for determination of lipid peroxidation (Klein 1970). Determination of thiobarbituric acidreactive substances (TBARS) formation was performed according to Das (1994). TBARS concentration was determined from the absorbance at $532 \mathrm{~nm}$.

\section{Data analysis}

The results are presented as mean \pm S.E.M. Oneway analysis of variance was first carried out to test for differences between groups. Differences between the means of the individual groups were assessed by Newman-Keuls test. A value of $p<0.05$ was considered to be statistically significant. 
Table 1. Effect of oxidative stress on cardiac sarcoplasmic reticulum vesicles.

\begin{tabular}{|c|c|c|}
\hline \multirow[t]{2}{*}{ Sample } & \multicolumn{2}{|c|}{$\begin{array}{c}\text { Fluorescence intensity } \\
\text { (arbitrary units) of }\end{array}$} \\
\hline & Tryptophan & Dityrosine \\
\hline 6 mo control & $65.4 \pm 0.62$ & $30.84 \pm 0.94$ \\
\hline $6 \mathrm{mo} O S$ & $53.99 \pm 1.23^{* * *}$ & $36.45 \pm 1.58^{*}$ \\
\hline 15 mo control & $76.68 \pm 1.89$ & $71.03 \pm 1.69$ \\
\hline $15 \mathrm{mo} \mathrm{OS}$ & $64.65 \pm 1.12^{* * *}$ & $77.53 \pm 1.15^{* *}$ \\
\hline 26 mo control & $80.88 \pm 0.72$ & $61.85 \pm 1.28$ \\
\hline 26 mo OS & $60.62 \pm 1.06 * * *$ & $71.11 \pm 1.59 * * *$ \\
\hline
\end{tabular}

OS - oxidative stress. Values are expressed as means \pm S.E.M. of 5 experiments. $* p<0.05$; $* * p<0.01 ; * * * p<0.001$; significantly different as compared to control.

Table 2. Effect of $\mathrm{H}_{2} \mathrm{O}_{2}, \mathrm{FeSO}_{4}$ /EDTA on fluorescence emission (Lym) and excitation (Lyx) of conjugates of lysine with lipid peroxidation products in rat heart sarcoplasmic reticulum vesicles.

\begin{tabular}{lll}
\hline Sample & \multicolumn{2}{c}{$\begin{array}{c}\text { Fluorescence intensity } \\
\text { (arbitrary units) of } \\
\text { Lym }\end{array}$} \\
& \multicolumn{1}{c}{$\mathbf{L y x}$} \\
\hline 6 mo control & $42.49 \pm 1.49$ & $43.12 \pm 1.49$ \\
6 mo OS & $56.06 \pm 1.96^{* * *}$ & $59.86 \pm 1.64 * * *$ \\
15 mo control & $48.16 \pm 0.79$ & $51.52 \pm 0.83$ \\
15 mo OS & $57.27 \pm 1.73^{* *}$ & $62.14 \pm 1.97 * *$ \\
26 mo control & $46.1 \pm 1$ & $44.09 \pm 0.87$ \\
26 mo OS & $59.41 \pm 1.38^{* * *}$ & $59.56 \pm 1.33^{* * *}$ \\
\hline
\end{tabular}

OS - oxidative stress. Values are expressed as means \pm S.E.M. of 5 experiments. $* * p<0.01 ; * * * p<0.001$; significantly different as compared to control.

\section{Results}

\section{Protein oxidative modification}

Effects of oxidative stress on protein structure were studied by measuring of tryptophan and dityrosine fluorescence. Amount of tryptophan was significantly decreased in consequence of in vitro induced oxidative stress in each age group (Table 1). The intensity of intrinsic tryptophan fluorescence was reduced by $17.4 \pm 1.8 \%$ in SR vesicles from adult animals compared to the control sample without treatment. Similar effect of oxidative stress we observed in group of old and senescent animals $(-17.8 \pm 1.4$ and $-25.0 \pm 1.3 \%)$.

The intensity of dityrosine fluorescence was elevated in the samples after free radical treatment (Table 1). Significant changes were observed in SR vesicles from of adult, old and senescent rats (18.2 \pm 5.1 , $9.2 \pm 1.6$ and $15.0 \pm 2.6 \%$ ).

\section{Oxidative modification of lysine}

The fluorescence intensity (excitation and emission spectra) of lysine conjugates with products of lipid peroxidation increased after induction of oxidative stress. Exposure of SR vesicles from adult rats caused $38.8 \pm 3.8 \%$ and $31.9 \pm 4.6 \%$ (Table 2) increase of excitation and emission fluorescence, respectively after $\mathrm{H}_{2} \mathrm{O}_{2}+\mathrm{FeSO}_{4} /$ EDTA treatment. Exposure of SR vesicles from old rats caused an increase by $20.6 \pm 3.8 \%$ and $18.9 \pm 3.6 \%$. Table 2 also shows that oxidative modification in cardiac SR vesicles form senescent rats enhanced to $135.1 \pm 3 \%$ and to $133.2 \pm 3.3 \%$, respectively compared to SR vesicles without treatment.

\section{ANS fluorescence intensity}

Fluorescence intensity of 1-anilino-8naphthalenesulfonate probe was decreased after induction of oxidative stress (Table 3). Exposure of old and senescent heart SR vesicles caused 6.1 \pm 3.5 and $10.6 \pm 1.4 \%$ decrease in ANS fluorescence.

\section{Levels of conjugated dienes and TBARS}

Modifications in lipid structure were assayed by measurement of changes in levels of conjugated dienes and determination of thiobarbituric acid-reactive substances (TBARS). Oxidative stress caused accumulation of conjugated dienes in cardiac sarcoplasmic reticulum vesicles (Fig. 1). In adult animals the level of conjugated dienes was elevated to $118.8 \pm 0.2 \%$. Levels of conjugated dienes increased to $115.1 \pm 0.4 \%$ in sarcoplasmic reticulum vesicles from old animals, and to $117.2 \pm 0.5 \%$ in sarcoplasmic reticulum of senescent animals.

Levels of TBARS elevated dramatically in each age group after induction of oxidative stress (Fig. 2). Levels of TBARS increased to $327.5 \pm 5.8,378.5 \pm 0.06$ and $427.4 \pm 2.3 \%$ with advancing age.

\section{Discussion}

There is growing evidence that protein oxidative damage is involved in aging process and disease. It is assumed that levels of ROS/RNS increase in aging process (Smith et al. 1991). In addition, with advancing 

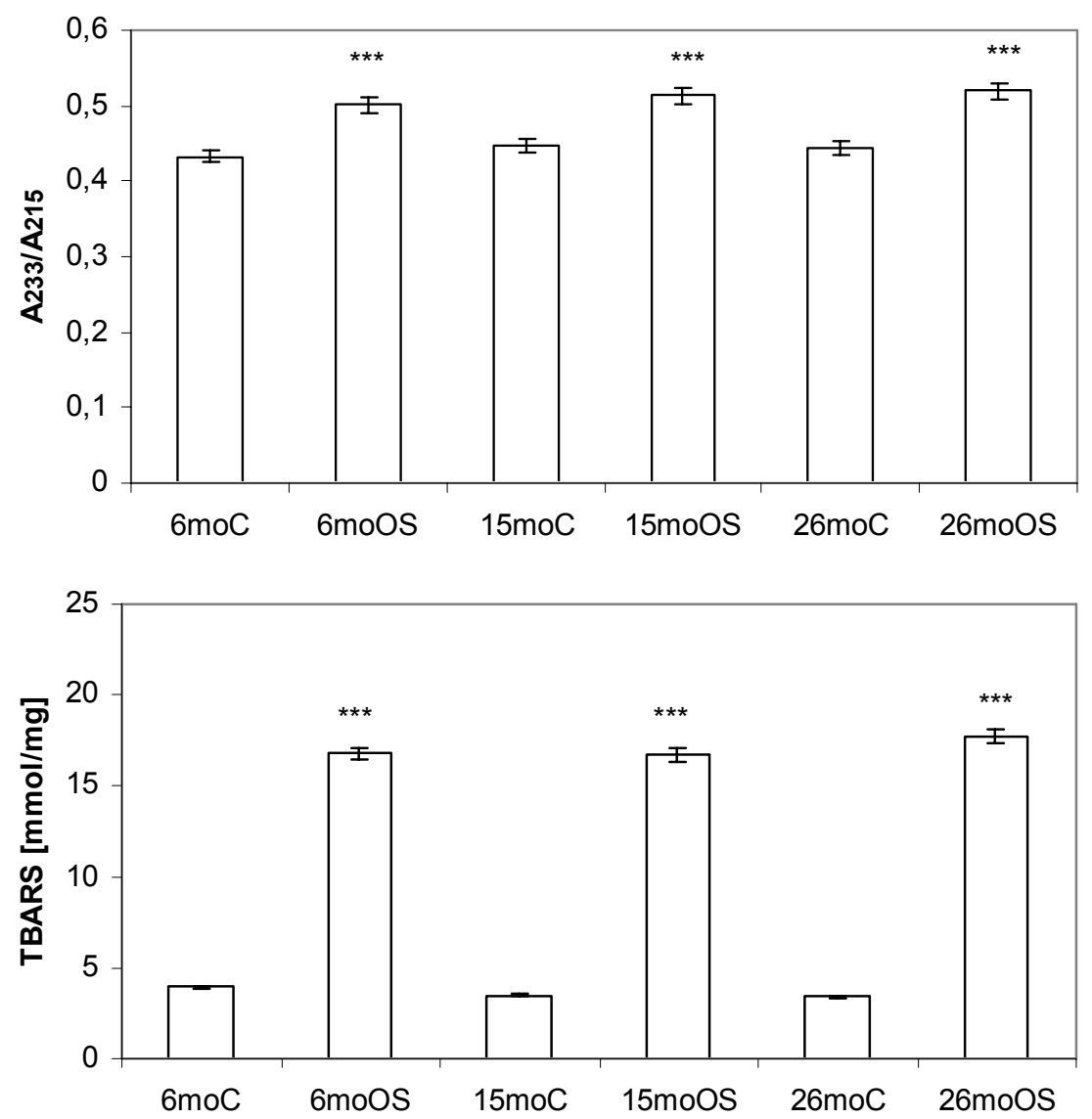

Fig. 1. Effect of $\mathrm{H}_{2} \mathrm{O}_{2}, \mathrm{FeSO}_{4} / \mathrm{EDTA}$ on conjugated dienes in heart sarcoplasmic reticulum vesicles. C control (vesicles without treatment), OS - oxidative stress. Values are expressed as means \pm S.E.M. of 5 experiments. $\quad * * * \quad p<0.001$; significantly different as compared to appropriate control.
Table 3. Effect of $\mathrm{H}_{2} \mathrm{O}_{2}, \mathrm{FeSO}_{4} /$ EDTA on fluorescence intensity of ANS.

\begin{tabular}{lc} 
Sample & $\begin{array}{c}\text { Fluorescence intensity } \\
\text { (arbitrary units) of 1,8-ANS } \\
\text { probe }\end{array}$ \\
\hline 6 mo control & $76.95 \pm 1.44$ \\
6 mo OS & $72.23 \pm 2.68$ \\
15 mo control & $94.24 \pm 1.54$ \\
26 mo OS & $89.76 \pm 1.11^{*}$ \\
26 mo $O S$ & $96.66 \pm 1.84$ \\
\hline
\end{tabular}

OS - oxidative stress. Values are expressed as means \pm S.E.M. of 5 experiments. $* p<0.05 ; * * p<0.01$; significantly different as compared to control (cardiac SR vesicles without treatment).

age antioxidant defense of organism deteriorates and susceptibility of biomolecules to oxidative stress may be elevated. In this study we have shown that oxidative damage to proteins and lipids of cardiac SR increases during in vitro generated oxidative stress. Oxidative damage increased in all age groups, but was the most pronounced in senescent rats.
Our previous studies demonstrated damaging effect of hydroxyl radicals on protein structure in cardiac mitochondria, myofibrils (Babušíková et al. 2004) and sarcoplasmic reticulum (Kaplán et al. 2003) in adult rats. It is assumed, that rise in the levels of iron and ROS with subsequent disturbance in $\mathrm{Ca}^{2+}$ homeostasis could be associated with cardiovascular diseases (Reddy and Clarck 2004, Chen et al. 2002, Ermak and Davies, 2002). SR plays an essential role in the regulation of intracellular $\mathrm{Ca}^{2+}$ concentration and cardiac contraction and relaxation. Although free-radical mediated dysfunction of SR was observed in numerous of studies (Morris and Sulakhe 1997, Xu et al. 1997, Kukreja et al. 1988) a mechanism of this damage is not yet completely understood. Levels of amino acid oxidative damage increased with advancing age in the control groups. Ageassociated damage was observed in the skeletal muscle and the heart of mice (Cakatay et al. 2003, Leeuwenburgh et al. 1997) and in rat brain (Babušíková et al. 2007). We observed significant protein and lipid oxidative damage after exposure of sarcoplamic reticulum vesicles to hydroxyl radicals. Levels of tryptophan decreased and levels of dityrosine and lysine conjugates increased in all age groups, however the most 
pronounced changes and the highest levels of investigated protein and lipid oxidative markers were observed in 26month-old animals. Amino acid residues such as Trp, Tyr and Lys have a crucial role in the function of $\mathrm{Ca}^{2+}$ ATPase (Andersen and Vilsen 1995, Yamagata et al. 1993) and their modifications can contribute to observed loss in function of $\mathrm{Ca}^{2+}$-ATPase during aging. Another important mechanism of SR dysfunction caused by ROS/RNS is related to alternation in membrane lipid bilayer. As shown fluorescence studies with ANS probe, SR membrane hydrophobicity was significantly altered by hydroxyl radicals. Consequently, changes in SR permeability to $\mathrm{Ca}^{2+}$ may contribute to disturbance of $\mathrm{Ca}^{2+}$ homeostasis. Moreover, lipid radicals or aldehydes formed during lipid peroxidation can react with Cys and Lys and inhibit membrane transport and enzymatic activities (Refsgaard et al. 2000). Changes in capacity to preserve a normal calcium homeostasis could be a base of reduced cell function in aging process and they can cause that senescent organisms are more sensitive to different diseases. Post-translation modifications as well as fundamental protein structural changes may result in agerelated decline.

In conclusion, presented study suggested increased oxidative modification of amino acids and lipid oxidation in heart sarcoplasmic reticulum vesicles with advancing age as well as with induced oxidative stress. Combination of amino acid and lipid modifications can cause cardiac contractile dysfunction and could be included in aging process and contribute to cardiovascular disease.

\section{Conflict of Interest}

There is no conflict of interest.

\section{Acknowledgements}

This work was partially supported by grants VEGA 1/0027/08, APVV 51-027404 and APVV 51-059505 from the Ministry of Education and Science of the Slovak Republic.

\section{References}

AMES BN, SHIGENASA MK, HAGEN TM: Oxidants, antioxidants, and the degenerative diseases of aging. Proc Natl Acad Sci USA 90: 7915-7922, 1993.

ANDERSEN JP, VILSEN B: Structure-function relationships of cation translocation by $\mathrm{Ca}^{2+}-$ and $^{+} \mathrm{Na}^{+}, \mathrm{K}^{+}-\mathrm{ATPases}$ studied by site-directed mutagenesis. FEBS Lett 359: 101-106, 1995.

BABUŠÍKOVÁ E, KAPLÁN P, LEHOTSKÝ J, JESEŇÁK M, DOBROTA D: Oxidative modification of rat cardiac mitochondrial membranes and myofibrils by hydroxyl radicals. Gen Physiol Biophys 23: 327-335, 2004.

BABUŠÍKOVÁ E, HATOK J, DOBROTA D, KAPLÁN: Age-related oxidative modifications of proteins and lipids in rat brain, Neurochem Res 32: 1351-1356, 2007.

BERGENDI L, BENEŠ L, ĎURAČKOVÁ Z, FERENČÍK M: Chemistry, physiology and pathology of free radicals. Biochem Biophys Res Commun 186: 782-789, 1999.

BERLETT BS, STADTMAN ER: Protein oxidation in aging, disease, and oxidative stress. J Biol Chem 272: 20313 20316, 1997.

BRAUGHLER JM, DUNCAN LA, CHASE RL: The involvement of iron in lipid peroxidation. J Biol Chem 261: 10282-10289, 1986.

CAKATAY U, TELCI A, KAYALI R, TEKELI F, AKCAY T, SIVAS A: Relation of aging with oxidative protein damage parameters in the rat skeletal muscle. Clin Biochem 36: 51-55, 2003.

CHEN YY, HO KP, XIA Q, QIAN ZM: Hydrogen peroxide enhances iron-induced injury in isolated heart and ventricular cardiomyocyte in rats. Mol Cell Biochem 231: 61-68, 2002.

DAS DK: Cellular, biochemical, and molecular aspects of reperfusion injury. Ann N Y Acad Sci 723: 118-124, 1994.

DAVIES KJA: Protein damage and degeneration by oxygen radicals. J Biol Chem 262: 9895-9901, 1987.

DEAN RT, FU S, STOCKER R, DAVIES MJ: Biochemistry and pathology of radical-mediated protein oxidation. Biochem J 324: 1-18, 1997.

DHALLA NS, TEMSAH RM, NETTICADAN T: Role of oxidative stress in cardiovascular diseases. J Hypertens 18 : 655-673, 2000.

DUPUY C, VIRION A, OHAYON R, KANIEWSKI J, DEME D, POMMIER J: Mechanism of hydrogen peroxide formation catalyzed by NADPH oxidase in thyroid plasma membrane. J Biol Chem 266: 3739-3743, 1991. 
ERMAK G, DAVIES KJ: Calcium and oxidative stress: from cell signaling to cell death. Mol Immunol 38: 713-721, 2002.

FU S, DAVIES J, DEAN RT: Molecular aspects of free radical damage to proteins. In: Molecular Biology of Free Radicals in Human Diseases. OI ARUOMA, B HALLIWELL (eds), 1998, OICA International, London, pp 29-56.

HALLIWELL B, GUTTERIDGE JMC: Role of free radicals and catalytic metal ions in human disease: an overview. Methods Enzymol 186: 1-85, 1990.

KAPLÁN P, BABUŠÍKOVÁ E, LEHOTSKÝ J, DOBROTA D: Free radical-induced protein modification and inhibition $\mathrm{Ca}^{2+}$-ATPase of cardiac sarcoplasmic reticulum. Mol Cell Biochem 248: 41-47, 2003.

KAPLÁN P, JURKOVIČOVÁ D, BABUŠÍKOVÁ E, HUDECOVÁ S, RAČAY P, SIROVÁ M, LEHOTSKÝ J, DRGOVÁ A, DOBROTA D, KRIŽANOVÁ O: Effect of aging on the expression of intracellular $\mathrm{Ca}^{2+}$ transport proteins in a rat heart. Mol Cell Biochem 301: 219-226, 2007.

KLEIN RA: The detection of oxidation in liposome preparations. Biochim Biophys Acta 210: 483-486, 1970.

KRAJČOVIČOVÁ-KUDLÁČKOVÁ M, DUŠINSKÁ M, VALACHOVIČOVÁ M, BLAŽÍČEK P, PAUKOVÁ V: Products of DNA, protein and lipid oxidative damage in relation to vitamin C plasma concentration. Physiol Res 55: 227-231, 2006.

KUKREJA RC, OKABE E, SCHRER GM, HESS ML: Oxygen radical-mediated peroxidation and inhibition of $\mathrm{Ca}^{2+}$ ATPase activity of cardiac sarcoplasmic reticulum. Arch Biochem Biophys 261: 447-457, 1988.

LEEUWENBURGH C, WAGNER P, HOLLOSYZ JO, SOHAL RS, HEINECKE JW: Caloric restriction attenuates dityrosine cross-linking of cardiac and skeletal muscle proteins in aging mice. Arch Biochem Biophys 346: 7480, 1997.

LOWRY OH, ROSEBROUGH NJ, FARR AL, RANDALL RJ: Protein measurement with the Folin phenol reagent. J Biol Chem 193: 265-275, 1951.

MORRIS TE, SULAKHE PV: Sarcoplasmic reticulum $\mathrm{Ca}^{2+}$-pump dysfunction in rat cardiomyocytes briefly exposed to hydroxyl radicals. Free Radical Biol Med 22: 37-47, 1997.

POLLACK M, LEEUWENBURGH CH: Molecular mechanisms of oxidative stress in aging: free radicals, aging, antioxidants and disease. In: Handbook of Oxidants and Antioxidants in Exercise. CK Sen, L Packer, O Hänninen (eds.), Elsevier Science, Amsterdam, 1999, pp 881-923.

REDDY MB, CLARK L: Iron, oxidative stress, and disease risk. Nutr Rev 62: 120-124, 2004.

REFSGAARD HH, TSAI L, STADTMAN ER: Modifications of proteins by polyunsaturated fatty acid peroxidation products. Proc Natl Acad Sci USA 97: 611-616, 2000.

REITER RJ: Oxidative damage in the central nervous system: protection by melatonin. Prog Neurobiol 56: 359-384, 1998.

SHRINGARPURE R, DAVIES KJ: Protein turnover by the proteasome in aging and disease. Free Radic Biol Med 32 : 1084-1089, 2002.

SIVOŇOVÁ M, TATARKOVÁ Z, ĎURAČKOVÁ Z, DOBROTA D, LEHOTSKÝ J, MATÁKOVÁ T, KAPLÁN P. Relationship between antioxidant potential and oxidative damage to lipids, proteins and DNA in aged rats. Physiol Res 56: 757-764, 2007.

SMITH CD, CARNEY JM, STARKE-REED PE, OLIVER CN, STADTMAN ER, FLOYD RA, MARKESBERY WR: Excess brain protein oxidation and enzyme dysfunction in normal aging and in Alzheimer disease. Proc Natl Acad Sci USA 88: 10540-10543, 1991.

SPITELLER G: Lipid peroxidation in aging and age-dependent diseases. Exp Gerontol 36: 1425-1457, 2001.

STADTMAN ER, BERLETT BS: Reactive oxygen-mediated protein oxidation in aging and disease. Chem Res Toxicol 10: 485-494, 1997.

XU KY, ZWEIER JL, BECKER LC: Hydroxyl radical inhibits sarcoplasmic reticulum $\mathrm{Ca}^{2+}$-ATPase function by direct attack on the ATP binding site. Circ Res 80: 76-81, 1997.

YAMAGATA K, DAIHO T, KANAZAWA T: Labeling of lysine 492 with pyridoxal 5'-phosphate in the sarcoplasmic reticulum $\mathrm{Ca}^{2+}$-ATPase. Lysine 492 residue is located outside the fluorescein 5-isothiocyanate-binding region in or near the ATP binding site. J Biol Chem 268: 20930-20936, 1993. 